\title{
Impact of Tribal Sub Plan (Tsp) on Livelihoods and Food Security of Tribal Fishermen
}

\author{
Abhishek Majhi* \\ Department of Economics, Sidho-Kanho-Birsha University, Purulia, West Bengal, India \\ *Corresponding author
}

\begin{tabular}{l} 
K e y w o r d s \\
Tribal Sub Plan, \\
Economic \\
Upliftment, \\
Statistical \\
Modelling, \\
Nutritional \\
Security, Tribal \\
Fishermen \\
\hline Article Info \\
\hline Accepted: \\
18 May 2020 \\
Available Online: \\
10 June 2020 \\
\hline
\end{tabular}

\section{A B S T R A C T}

\section{Introduction}

For the process of development of the tribal people, it require management of land base, forest, fisheries, water resources, etc, where open access is there inefficient utilisation has resulted in faster depletion of these resources, less sustainment and as a result, environment degradation. It is evident that even if a ten percent higher efficient utilization is effected by and through avoidance of wastages, a substantial proportion of these resources can be sustainably conserved. Too much crowding for resource exploitation and lack of competitive prices have resulted in an uneconomical infrastructure, superfluous competitions misidentification of priorities lack of appropriate technologization, underplay of local interest and several other problems. Proper management of the commons imply more opportunities for the poor and better distribution of power. 
This is also essential to really decentrali the overall decision making process and avoid over concentration of various interests. Total fish production in the world which was around 20 million tonnes in the 40's increased to over 110 million tonnes in 1990 (FAO 2004. The State of World Fisheries and Aquaculture). In this, the increase in marine fish catch is higher than that of inland source. After the seventies, there has been a diminishing increase in marine fish catch. In the seventies and early eighties, the rate of increase was less than one per cent a year. The main reason for decline in the annual rate of increase has been the limited size of stocks of fish species. Some of these species are already overexploited while others are nearing the limits of capacity. Meanwhile the vulnerability of the production system and the necessity to diversify the existing production process beyond the conventional methods incorporated. Further, most of the potential expansion in marine fish catch would come from increased fishing, requiring a huge capital investment in fishing boats and gear which might entail in declining returns per unit of effort for all fishermen (FAO, Committee on Fisheries). The developed countries account of about 60 per cent of fish catch with a per capita fish consumption of over $30 \mathrm{kgs}$ per annum (Handbook of Fisheries Statistics 1991, Ministry of Agriculture, Govt. of India, New Delhi, 1991). Whereas, in some developing countries the per capita consumption could be less than $5 \mathrm{kgs}$. with the establishment of exclusive economic zones within 200 nautical miles of the shorelines.

Fisheries management has to be improved by developing and adhering to the eco-system conservation principle called unit management wherein all associated species, relevant habitats and spread outs and necessitated areas are jointly managed. Regulation of catch, entry of vessels, developing endogenous technology for management and provision of marketing and other infrastructures to both capture and artisanal fishermen would improve sustainability and pollution control of the coastal areas. Losses in catch, storage and transport have to be minimised. Improving aquaculture technology would sustain fisheries so as to supplement agriculture and biodiversity.

Unlike agricultural production which can be greatly expanded by the use of suitable technology, productivity of marine organism is limited by the chemical and physical properties of ocean water (Swaminathan, 1985). The realisation of limited fish stock has necessitated ocean enclosure movement called exclusive economic zone of the coastal countries. The open access characteristics in addition to the limited quantity of resources that can be effectively exploited give rise for a better management. The objectives of such management are to maximise the social and economic benefits of fisheries to concerned marine population and their habitats and to improve international relations thereby (Varma, 1992). Effective management depends on the availability of relevant data which seem to be lacking in many countries. In the case of freshwater aquaculture resources in India it comprises of small and large seasonal and perennial ponds and tanks, beals, jheels, lakes, canals, reservoirs, rivers, swamps, paddy fields and a few brackish water bheris, which have been recently added in the freshwater community. In the past water resources in the rural areas had harboured abundant wild fish. These wild fish were used to meet the requirement of the people and due to this people showed little interest in fish culture. Even then fish farming had been a traditional practice dating back to several centuries, when the country was ruled by Hindu kings. The rulers used to excavate ponds and tanks for drinking, bathing and 
sometimes for small scale irrigation purposes. These ponds and tanks were used for fish keeping aimed for recreation and games rather than for commercial purposes. Tanks were also found in the temple boundaries and fish from natural resources were caught and reared in those temple tanks. People coming to the temple used to feed the fish and fish were caught and auctioned periodically after 4-5 years. The money earned was used for the welfare of the temple owners. History narrates that fish culture in India was on a limited scale since 300 B.C. Attempt on scientific fish culture was first made in Madras somewhere in 1911 and culture on scientific lines was practised in Bengal during the same period. In the 20th century fish culture practices were extended to other parts of the country through establishment of Fisheries Departments in the states. It was then established that the success in aquaculture can be achieved by good breed, quality seed and nutritive feed as green revolution in agriculture was achieved by quality seed, suitable fertilizer and proper irrigation. Fisheries represent a vital sector in the thrust Programme of West Bengal Government for rural development through production of fish and other ancillary activities thereby generating rural employment and improvement of socio economic status of the fishers who are the prime contributors of fisheries production.

\section{Materials and Methods}

The present study is based on an intensive fieldwork conducted in Arsha \& Bagmundi blocks of Purulia district, West Bengal during the months of February 2017 to July 2017. Before the commencement of fieldwork, a pilot study was conducted during the month of January 2014. Based on that pilot study, Arsha \& Bagmundi blocks of Purulia district were selected for final study. Purposive sampling method was used while selecting the study area.
Purulia came into force as a district of West Bengal in 1956. Purulia is the western-most district of West Bengal with an all-India significance because of its tropical location, its shape as well as function like a funnel. It funnels not only the tropical monsoon current from the Bay to the subtropical parts of northwest India, but also acts as a gateway between the developed industrial belts of West Bengal and the hinterlands in Orissa, Jharkhand, Madhya Pradesh and Uttar Pradesh. This district is between $22^{\circ} 42^{\prime} 35^{\prime \prime}$ and $23^{\circ} 42^{\prime} 0^{\prime \prime}$ north latitude and $85^{\circ} 49^{\prime} 25^{\prime \prime}$ and $86^{\circ} 54^{\prime} 37^{\prime \prime}$ east longitude. Midnapore, Bankura and Burdwan district of West Bengal and Dhanbad, Bokaro, Hazaribagh, Ranchi, West Singbhum, East Singbhum district of Jharkhand State bound this district. The total geographical area of the district is 6259 sq. kms. Out of which the Urban and Rural areas are 79.37 sq. kms (1.27\%) (Municipalities \& Non-Municipalities) and 6179.63 sq. kms $(98.73 \%)$ respectively.

Physiographically, Purulia, the westernmost district of West Bengal, is well known as a drought prone district and falls within the semi-arid region of the state. Cultivation of this district is predominantly mono-cropped. Out of total geographical land $52.47 \%$ are used for agriculture. $29.69 \%$ are under forest coverage (including social forestry) and 10.15 $\%$ are identified as Wasteland. Soil erosion is the most prominent phenomenon of the district resulting huge deposition of fertile soil in the valley region. Vast areas of land remained uncultivable wasteland. Out of the total agricultural holding about $73 \%$ belongs to small and marginal farmers having scattered and fragmented smallholding. About $90 \%$ of the population lives in villages and about $44 \%$ of the rural population is below poverty line. As per 2001 census total population of the district is 2535516, out of which $89.93 \%$ are residing in rural areas and $10.07 \%$ are in urban areas. 
About $51.18 \%$ of the populations are males and $48.82 \%$ are female. The percentage of Scheduled Caste and Scheduled Tribes are $18.29 \%$ and $18.27 \%$. Total no of BPL families in rural areas of this district are 197381 (43.65 \%). Out of which SC families are $40645(20.59 \%)$ and ST families are 47666 (24.15\%). Total no. of BPL families in Purulia and Jhalda Municipality are 2573 $(11.31 \%)$ and 571(15.98\%) respectively (District Statistical Handbook, 2013. Bureau of Applied Economics \& Statistics, Purulia, Govt. of West Bengal)

The three main advantages of sampling are that the cost is lower, data collection is faster, and since the data set is smaller it is possible to ensure homogeneity and to improve the accuracy and quality of the data. Sampling is concerned with the selection of a subset of individuals from within a population to estimate characteristics of the whole population which is homogeneous in nature. Sampling is the process of selecting units likes people, organizations from a population of interest so that by studying the sample we may fairly generalize our results back to the population from which they were chosen. Using random sampling method around 50 tribal fisher folk were selected for final study.

\section{Results and Discussion}

Concise analytical discussion for average economics (unit $1,333.33 \mathrm{~m}^{2}$ ) in connection with total output for tribal fish farming considering all the involved parameters over arsha dev. block under culture of tribal sub plan

From (Table 1) it depicted the bivariate intercorrelation among all the variables (average value calculated for 1 bigha area, in all the cases) viz. pond preparation, transport, raw cow dung, netting during culture, labour charge, harvesting cost, total input and total output under consideration. Firstly, considering the correlation between pond preparation with other variables, there exist a significant moderate positive correlation with netting during culture, low positive correlation with transport and total output, low negative correlation with total output, moderate negative correlation with labour charge.

Secondly, considering the correlation between transport with other variables, there exist a significant high positive correlation with raw cow dung, moderate positive correlation with total input and total output, low positive correlation with Medicine/Prophylactics, labour charge and harvesting cost, moderate negative correlation with netting during culture.

Thirdly, considering the correlation between raw cow dung with other variables, there exist a significant moderate positive correlation with harvesting cost, total input and total output, low positive correlation with medicine/prophylactics and labour charge, moderate negative correlation with netting during culture.

Fourthly, considering the correlation between netting during culture with other variables, there exist a significant low positive correlation with medicine/ prophylactics, moderate negative correlation with harvesting cost, total input and total output, high negative correlation with labour charge.

Fifthly, considering the correlation between medicine/prophylactics with other variables, there exist a significant moderate positive correlation with total input, low positive correlation with labour charge, harvesting cost and total output. Sixthly, considering the correlation between labour charge with other variables, there exist a significant high positive correlation with total input, moderate 
positive correlation with harvesting cost, low positive correlation with total output.

Seventhly, considering the correlation between harvesting cost with other variables, there exist a significant high positive correlation with total output, moderate positive correlation with total input.

Finally, considering the correlation between total input with other variables, there exist a significant moderate positive correlation with total output.

From (Table 2), The linear regression equation taking total input as dependent variable and other variables viz. pond preparation, transport, raw cow dung, netting during culture, medicine/prophylactics, labour charge and harvesting cost as independent variables. The equation revealed as below:

Total Input $=-10500.000+$ pond preparation + transport $+(-5.857$ x raw cow dung $)+$ netting during culture + medicine/ prophylactics $+(1.305 \times$ labour charge $)+$ harvesting cost.

The equation clearly indicates the most important variable (average value calculated for 1 bigha area, in all the cases) is raw cow dung. It is negative impact upon Total input. All the other independent variables have positive impact upon total input. The $95 \%$ Confidence Interval i.e. the lower and the Upper boundaries are depicted as: pond preparation $(-1.000,1.000)$, transport $(-1.000$, 1.000), raw cow dung $(-5.857,5.857)$, netting during culture $(-1.000, \quad 1.000)$, medicine/prophylactics $(-1.000,1.000)$, labour charge $(-1.305,1.305)$, harvesting cost $(-1.000,1.000)$.

From (Table 3), The linear regression equation taking total output as dependent variable and other variables viz. pond preparation, transport, raw cow dung, netting during culture, medicine/prophylactics, labour charge and harvesting cost as independent variables. The equation revealed as below:

Total Output $=-2937.723+(-.014 \times$ pond preparation $)+(.028 \times$ transport $)+(15.801 \times$ raw cow dung $)+(-.422 \mathrm{x}$ netting during culture $)+(-3.391 \times$ medicine/prophylactics $)+$ $(-.732 \times$ labour charge $)+(43.555 \times$ harvesting cost).

The equation clearly indicates the most important variables (average value calculated for 1 bigha area, in all the cases) are raw cow dung and harvesting cost. Both of them have positive impact upon Total output. All the other independent variables viz. pond preparation, netting during culture, medicine/prophylactics and labour charge have negative impact upon total output, and transport has positive impact upon total output. The 95\% Confidence Interval i.e. the lower and the Upper boundaries are depicted as: pond preparation $(-4.894,4.866)$, transport $(-4.323,4.379)$, raw cow dung $(-50.512$, $82.115)$, netting during culture (-9.680, 8.836), medicine/prophylactics $\quad(-39.557$, 32.776), labour charge $(-2.582,3.285)$, harvesting cost $(-5.520,81.589)$.

Concise analytical discussion for average economics (unit $1,333.33 \mathrm{~m}^{2}$ ) in connection with total output for tribal fish farming considering all the involved parameters over bagmundi dev. block under culture of tribal sub plan

From (Table 4) it depicted the bivariate intercorrelation among all the variables (average value calculated for 1 bigha area, in all the cases) viz. pond preparation, transport, raw cow dung, netting during culture, Medicine/Prophylactics, labour charge, harvesting cost, total input and total output under consideration. 
Firstly, considering the correlation between pond preparation with other variables, there exist a significant moderate positive correlation with transport, Medicine/ Prophylactics, total input and total output, low negative correlation with raw cow dung, netting during culture, labour charge, harvesting cost.

Secondly, considering the correlation between transport with other variables, there exist a significant high positive correlation with Medicine/Prophylactics, total input and total output, low positive correlation with labour charge, high negative correlation with raw cow dung, moderate negative correlation with netting during culture, low negative correlation with harvesting cost.

Thirdly, considering the correlation between raw cow dung with other variables, there exist a significant moderate positive correlation with netting during culture, low positive correlation with harvesting cost, high negative correlation with Medicine/Prophylactics, moderate negative correlation with total input and total output, low negative correlation with labour charge.

Fourthly, considering the correlation between netting during culture with other variables, there exist a significant low positive correlation with harvesting cost, high negative correlation with Medicine/Prophylactics and total input, moderate negative correlation with labour charge and total output.

Fifthly, considering the correlation between medicine/prophylactics with other variables, there exist a significant high positive correlation with total input and total output, moderate positive correlation with labour charge, low negative correlation with harvesting cost. Sixthly, considering the correlation between labour charge with other variables, there exist a significant moderate positive correlation with harvesting cost, total input and total output.

Seventhly, considering the correlation between harvesting cost with other variables, there exist a significant low positive correlation with total output and low negative correlation with total input.

Finally, considering the correlation between total input with other variables, there exist a significant high positive correlation with total output

From (Table 5), The linear regression equation taking total input as dependent variable and other variables viz. pond preparation, raw cow dung, netting during culture, medicine/prophylactics, labour charge and harvesting cost as independent variables. The equation revealed as below:

Total Input $=979.730+(.990 \mathrm{x}$ pond preparation $)+(1.507 \times$ raw cow dung $)+$ (1.203 x netting during culture $)+(27.182 \mathrm{x}$ medicine/prophylactics $)+(.883 \mathrm{x}$ labour charge $)+(-8.291 \times$ harvesting cost $)$.

The equation clearly indicates the most important variables (average value calculated for 1 bigha area, in all the cases) are medicine/prophylactics and harvesting cost, where medicine/prophylactics is positive impact upon Total input and harvesting cost is negative impact upon Total input.

All the other independent variables have positive impact upon total input. The $95 \%$ Confidence Interval i.e. the lower and the Upper boundaries are depicted as: pond preparation $(-.990, .990)$, raw cow dung ($1.507,1.507)$, netting during culture $(-1.203$, 1.203), medicine/prophylactics $(-27.182$, 27.182), labour charge $(-.883, .883)$, harvesting cost $(-8.291, \quad 8.291)$. 
Table.1 Correlation Matrix for Average Economics (unit 1bigha) comprising all culture under Tribal Sub Plan of Arsha Block in connection with Tribal Fish Farming

\begin{tabular}{|c|c|c|c|c|c|c|c|c|c|}
\hline & $\begin{array}{l}\text { Pond } \\
\text { Preparat } \\
\text { ion }\end{array}$ & $\begin{array}{c}\text { Transport } \\
\text { (Seed,Feed,Manu } \\
\text { re etc.) }\end{array}$ & $\begin{array}{l}\text { Raw Cow } \\
\text { Dung }\end{array}$ & $\begin{array}{l}\text { Netting } \\
\text { during } \\
\text { culture }\end{array}$ & $\begin{array}{l}\text { Medicine } \\
\text { /Prophylact } \\
\text { ics }\end{array}$ & $\begin{array}{l}\text { Labour } \\
\text { Charge }\end{array}$ & $\begin{array}{l}\text { Harvesting } \\
\text { cost }\end{array}$ & $\begin{array}{l}\text { Total } \\
\text { Input }\end{array}$ & $\begin{array}{c}\text { Total } \\
\text { Output }\end{array}$ \\
\hline Pond Preparation & 1 & & & & & & & & \\
\hline $\begin{array}{l}\text { Transport (Seed,Feed, } \\
\text { Manure etc.) }\end{array}$ & .239 & 1 & & & & & & & \\
\hline Raw Cow Dung & .000 & $.910(* *)$ & 1 & & & & & & \\
\hline Netting during culture & .530 & -.491 & $-.640(*)$ & 1 & & & & & \\
\hline Medicine/Prophylactics & .000 & .138 & .258 & .092 & 1 & & & & \\
\hline Labour Charge & $-.733(*)$ & .130 & .375 & $-.861(* *)$ & .181 & 1 & & & \\
\hline Harvesting cost & .000 & .375 & .500 & -.557 & .323 & .515 & 1 & & \\
\hline Total input & -.318 & .508 & $.649(*)$ & $-.776(* *)$ & .463 & $.835(* *)$ & $.679(*)$ & 1 & \\
\hline Total output & .291 & $.657(*)$ & $.686(*)$ & -.458 & .162 & .203 & $.870(* *)$ & .487 & 1 \\
\hline
\end{tabular}

* Correlation is significant at the 0.05 level (2-tailed).

** Correlation is significant at the 0.01 level (2-tailed)

Table.2 Coefficients Matrix for Average Economics (unit 1bigha) comprising all culture under Tribal Sub Plan of Arsha Block in connection with Tribal Fish Farming

\begin{tabular}{|c|c|c|c|}
\hline & \multirow{2}{*}{$\begin{array}{l}\text { Unstandardized } \\
\text { Coefficients }\end{array}$} & \multicolumn{2}{|c|}{ 95\% Confidence Interval for B } \\
\hline & & Lower Bound & Upper Bound \\
\hline (Constant) & 4342.857 & -4342.857 & 4342.857 \\
\hline Pond Preparation & 1.000 & -1.000 & 1.000 \\
\hline $\begin{array}{l}\text { Transport } \\
\text { (Seed, Feed, Manure etc.) }\end{array}$ & 1.000 & -1.000 & 1.000 \\
\hline Raw Cow Dung & -5.857 & -5.857 & 5.857 \\
\hline Netting during culture & 1.000 & -1.000 & 1.000 \\
\hline Medicine/Prophylactics & 1.000 & -1.000 & 1.000 \\
\hline Labour Charge & 1.305 & -1.305 & 1.305 \\
\hline Harvesting cost & 1.000 & -1.000 & 1.000 \\
\hline
\end{tabular}

Table.3 Coefficients Matrix for Average Economics (unit 1bigha) comprising all culture under Tribal Sub Plan of Arsha Block in connection with Tribal Fish Farming

\begin{tabular}{|l|r|r|r|}
\hline & \multicolumn{2}{|l|}{$\begin{array}{l}\text { Unstandardized } \\
\text { Coefficients }\end{array}$} & \multicolumn{2}{l|}{ 95\% Confidence Interval for B } \\
\cline { 2 - 4 } & \multicolumn{2}{l|}{ Lower Bound } & Upper Bound \\
\hline (Constant) & -2937.723 & -67219.396 & 61343.950 \\
\hline Pond Preparation & -.014 & -4.894 & 4.866 \\
\hline $\begin{array}{l}\text { Transport (Seed, Feed, Manure } \\
\text { etc.) }\end{array}$ & -028 & -4.323 & 4.379 \\
\hline Raw Cow Dung & & & 82.115 \\
\hline Netting during culture & 15.801 & -50.512 & 8.836 \\
\hline Medicine/Prophylactics & -.422 & -9.680 & 32.776 \\
\hline Labour Charge & -3.391 & -39.557 & 3.078 \\
\hline Harvesting cost & -.732 & -4.542 & 81.589 \\
\hline
\end{tabular}

Dependent Variable: Total Output 
Table.4 Correlation Matrix for Average Economics (unit 1bigha) comprising all culture under Tribal Sub Plan of Bagmundi Block in connection with Tribal Fish Farming

\begin{tabular}{|c|c|c|c|c|c|c|c|c|c|}
\hline & $\begin{array}{c}\text { Pond } \\
\text { Preparation }\end{array}$ & $\begin{array}{c}\text { Transport } \\
\text { (Seed,Feed,M } \\
\text { anure etc.) }\end{array}$ & $\begin{array}{l}\text { Raw } \\
\text { Cow } \\
\text { Dung }\end{array}$ & $\begin{array}{l}\text { Netting } \\
\text { during } \\
\text { culture }\end{array}$ & $\begin{array}{c}\text { Medicine } \\
\text { /Prophylactics }\end{array}$ & $\begin{array}{l}\text { Labour } \\
\text { Charge }\end{array}$ & $\begin{array}{c}\text { Harvesti } \\
\text { ng cost }\end{array}$ & $\begin{array}{l}\text { Total } \\
\text { Input }\end{array}$ & $\begin{array}{c}\text { Total } \\
\text { Output }\end{array}$ \\
\hline Pond Preparation & 1 & & & & & & & & \\
\hline $\begin{array}{l}\text { Transport } \\
\text { (Seed,Feed,Manure } \\
\text { etc.) }\end{array}$ & .720 & 1 & & & & & & & \\
\hline Raw Cow Dung & -.389 & $-.801(*)$ & 1 & & & & & & \\
\hline $\begin{array}{l}\text { Netting during } \\
\text { culture }\end{array}$ & -.338 & $-.778(*)$ & .531 & 1 & & & & & \\
\hline $\begin{array}{l}\text { Medicine/Prophylact } \\
\text { ics }\end{array}$ & .644 & $.982(* *)$ & $-.811(*)$ & $-.831(*)$ & 1 & & & & \\
\hline Labour Charge & -.202 & .317 & -.382 & -.733 & .471 & 1 & & & \\
\hline Harvesting cost & -.306 & -.271 & .125 & .137 & -.112 & .411 & 1 & & \\
\hline Total input & .668 & $.953(* *)$ & $-.788(*)$ & $-.830(*)$ & $.986(* *)$ & .523 & -.031 & 1 & \\
\hline Total output & .628 & $.910(* *)$ & $-.772(*)$ & -.700 & $.947(* *)$ & .446 & .098 & $.952(* *)$ & 1 \\
\hline
\end{tabular}

* Correlation is significant at the 0.05 level (2-tailed).

** Correlation is significant at the 0.01 level (2-tailed).

Table.5 Coefficients Matrix for Average Economics (unit 1bigha) comprising all culture under Tribal Sub Plan of Bagmundi Block in connection with Tribal Fish Farming

\begin{tabular}{|l|c|c|c|}
\hline & \multirow{2}{*}{$\begin{array}{c}\text { Unstandardized } \\
\text { Coefficients }\end{array}$} & \multicolumn{2}{|c|}{ 95\% Confidence Interval for B } \\
\cline { 3 - 4 } & & Lower Bound & Upper Bound \\
\hline (Constant) & 979.730 & -979.730 & 979.730 \\
\hline Pond Preparation & .990 & -.990 & .990 \\
\hline Raw Cow Dung & 1.507 & -1.507 & 1.507 \\
\hline Netting during culture & 1.203 & -1.203 & 1.203 \\
\hline Medicine/Prophylactics & 27.182 & -27.182 & 27.182 \\
\hline Labour Charge & .883 & -.883 & .883 \\
\hline Harvesting cost & -8.291 & -8.291 & 8.291 \\
\hline
\end{tabular}

Dependent Variable: Total Input

Table.6 Coefficients Matrix for Average Economics (unit 1bigha) comprising all culture under Tribal Sub Plan of Bagmundi Block in connection with Tribal Fish Farming

\begin{tabular}{|l|c|c|c|}
\hline & $\begin{array}{c}\text { Unstandardized } \\
\text { Coefficients }\end{array}$ & \multicolumn{2}{|c|}{$\mathbf{9 5 \%}$ Confidence Interval for B } \\
\cline { 3 - 4 } & & Lower Bound & Upper Bound \\
\hline (Constant) & -23438.280 & -23438.280 & 23438.280 \\
\hline Pond Preparation & -7.063 & -7.063 & 7.063 \\
\hline Raw Cow Dung & 32.486 & -32.486 & 32.486 \\
\hline Netting during culture & 9.222 & -9.222 & 9.222 \\
\hline Labour Charge & -.048 & -.048 & .048 \\
\hline Harvesting cost & -80.465 & -80.465 & 80.465 \\
\hline
\end{tabular}

Dependent Variable: Total Output 
From (Table 6), the linear regression equation taking total output as dependent variable and other variables viz. pond preparation, raw cow dung, netting during culture, labour charge and harvesting cost as independent variables. The equation revealed as below:

Total Output $=-23438.280+(-7.063 \times$ pond preparation $)+(32.486 \mathrm{x}$ raw cow dung $)+$ (9.222 $\mathrm{x}$ netting during culture $)+(-.048 \mathrm{x}$ labour charge $)+(-80.465 \mathrm{x}$ harvesting cost $)$.

The equation clearly indicates the most important variables (average value calculated for 1 bigha area, in all the cases) are raw cow dung and harvesting cost, where raw cow dung is positive impact upon total output and harvesting cost is negative impact upon total output. All the other independent variables viz. pond preparation and labour charge have negative impact upon total output, and netting during culture has positive impact upon total output. The $95 \%$ Confidence Interval i.e. the lower and the Upper boundaries are depicted as: pond preparation $(-7.063,7.063)$, raw cow dung $(-32.486,32.486)$, netting during culture $(-9.222,9.222)$, labour charge $(-.048, .048)$, harvesting cost $(-80.465,80.465)$.

In West Bengal, Purulia District is one of the poorly backward drought prone, topographically severely undulating lands with inadequate irrigation and insufficient of all agricultural inputs. The present status of tribal people is very poor as a consequence they are migrating to neighboring district and state for their source of income. Fishermen contribute a lot in our economy. So improvement of their social life and economic condition is very important in context our national economic development. And for that proper management of capture fisheries should be done properly. Fishermen villages are mostly located in inaccessible areas, where there is little communication and developmental or social impact. There is no denying the fact that fishermen and fishing community as a whole the poorest and most disadvantaged group of Purulia. They have no other income generating activities except fishing, which cannot be carried out throughout the year and in idle periods, they lack alternative employment opportunities. Their socio-economic development is negligible. Hence it is essential to know the livelihood status of fishermen. For the overall planning, and development and implementation in fisheries sector, it is necessary to have the sound knowledge about the livelihood pattern of the related people. Relatively in any practical field, socioeconomic condition illustrates the present status, standard of living and economic condition of the people. In fact income earning activities as an outcome of socioeconomic pattern which are affected by the community environment, is one of the most obvious issue that had not been conducted in the area. So in this respect, this study is very much important. Therefore proper fishery management policies, effective input supply, technical and social support may improve the livelihood of the fishers which will ultimately increase the overall fisheries productivity of Purulia district as well as West Bengal.

\section{References}

Awais, M. and Ahmad, R. (2013). An analytical study of socio-economic condition of tribal farmers in Bijnor district of U.P. State.

Bandyopadhyay K. Pradip.1999. Tribal Situation in Eastern India, Customary Laws among Border Bengal Tribes Gupta Press, Calcutta, Pp. 49-50.

Chaudhuri, H. and K.H. Alikunhi. 1957 Observations on the breeding of Indian carps by hormone injection. $\underline{\text { Curr. }}$ Sci. 26 (12), 381-382.

Comprehensive District Agricultural Plan Under Rashtriya Krishi Vikas Yojana, 
Purulia, West Bengal.

FAO 2004. The State of World Fisheries and Aquaculture.

Handbook of Fisheries Statistics 1991, Ministry of Agriculture, Govt. of India, New Delhi, 1991.

Majhi, A. (2014). Comparative bio-economics of tribal fisherfolk at selected regions of purulia district: before and after implementation of TSP (tribal sub plan) programme. M.F.Sc. Thesis. West Bengal University of Animal and Fishery Sciences.
Repetto, R. ed. The Global Possible, Resources, Development and the New Country,Affiliated East- West Press, New Delhi, 1990. Appendix p. 507

Roy, D. (2012). Socio-economic status of Schedule tribes in Jhakhand.

Swaminathan, M. S. (1985). Imparting rural women perspective to agriculture research and development. Report of the Project Design Workshop on Women in Farming Systems, held At the International Rice Research Centre, Los Banos, Phillippines, April 10.

\section{How to cite this article:}

Abhishek Majhi. 2020. Impact of Tribal Sub Plan (Tsp) on Livelihoods and Food Security of Tribal Fishermen. Int.J.Curr.Microbiol.App.Sci. 9(06): 932-941.

doi: https://doi.org/10.20546/ijcmas.2020.906.117 